\title{
Early effects of intravenous terbutaline on cardiopulmonary function in chronic obstructive bronchitis and pulmonary
} hypertension

\author{
RM JONES, RA STOCKLEY, JM BISHOP \\ From the University Department of Medicine, Queen Elizabeth Hospital, and the General Hospital, Birmingham
}

ABSTRACT Terbutaline sulphate $(0.25 \mathrm{mg})$ was given intravenously to 10 recumbent patients with severe irreversible airflow obstruction and pulmonary hypertension who were undergoing right heart catheterisation. Alveolar ventilation index, cardiac index, and mean pulmonary artery pressure all rose sig. nificantly at 5 minutes and then fell by 35 minutes, although the first two remained higher than control levels. This was accompanied by a small but significant rise in arterial oxygen tension at 5 minutes. There were no significant changes in ventilation-perfusion relationships at either 5 or 35 minutes.

Beta-adrenergic-stimulating drugs are frequently given intravenously in the treatment of exacerbations of airflow obstruction resulting from both asthma and chronic bronchitis. These drugs may aggravate existing hypoxaemia in both asthma ${ }^{1-3}$ and chronicbronchitis ${ }^{2.4 \cdot 6}$ by adversely affecting ventilation-perfusion relationships. This is thought to be due to the combination of the increase in cardiac output produced by the $\beta$, activity of the drug and pulmonary and systemic vasodilatation produced by the $\beta_{2}$ activity, ${ }^{7-9}$ both effects resulting in an increase in intrapulmonary shunting and venous admixture. This may be partially offset in patients with reversible airflow obstruction by bronchodilatation and increased alveolar ventilation. ${ }^{1-4}$ Patients with severe fixed airflow obstruction and pulmonary hypertension, however, may not respond in a similar way and may be at greater risk of developing further hypoxaemia after treatment.

Terbutaline is less likely to cause increased hypoxaemia because it is a relatively selective $\beta_{2}$-adrenergic agonist, ${ }^{10.12}$ having little $\beta_{1}$ effect on cardiac output and hence on the pulmonary circulation, ${ }^{13-16}$ although a reduction in arterial oxygen tension $\left(\mathrm{PaO}_{2}\right)$ does occur in some patients when it is given by the parenteral routes. ${ }^{17-18}$

Stockley et a ${ }^{19}$ showed a small but significant increase in venous admixture in patients with chronic bronchitis and pulmonary hypertension 40 minutes after an intravenous dose of terbutaline, without a fall in arterial oxygen tension. The doses of terbutaline, however, were small. Using a larger intravenous dose, Teule et al ${ }^{1 ?}$ found no significant change in venous admixture, but

Address for reprint requests: Dr RA Stockley, General Hospital, Steclhouse Lane, Birmingham $\mathrm{B} 46 \mathrm{NH}$. there was a slight fall in $\mathrm{PaO}_{2}$ after 20 minutes in patients with chronic obstructive bronchitis but without clinical cor pulmonale. Peak serum concentrations of terbutaline, however, occur about five minutes after an intravenous bolus ${ }^{20}$ and thus any effects on cardiopulmonary function should be maximal at this time and thereafter decline.

The purpose of the present study was to investigate the early cardiopulmonary changes occurring afteran intravenous bolus of terbutaline in a group of patients with severe fixed airflow obstruction and pulmonary hypertension. In particular, we were interested in any adverse effect on ventilation-perfusion relationships and arterial oxygen tension.

\section{Methods}

Ten patients (table) with chronic obstructive bronchitis were studied; none had any significant improvement in airflow obstruction following inhaled bronchodilators. All were hypoxaemic at rest and had experienced at least one episode of cardiac failure with oedema. The patients were being assessed for long-term domiciliary oxygen treatment in accordance with the criteria for the Medical Research Council trial and were studied in a stable clinical state at least six weeks after any episode of cardiac failure or respiratory infection. Some were receiving digoxin and all were taking diuretics. Bronchodilator and oxygen treatment were discontinued at least 24 hours before investigation. All patients gave informed consent to the catheterisation as part of the protocol of the MRC trial. All were informed of the nature of the additional drug study and told that we wished to monitor the effect of terbutaline on the cardio- 
Details of lung function in patients studied (values in parentheses are those predicted for the patients'age and height ${ }^{24}$ )

\begin{tabular}{|c|c|c|c|c|c|c|c|c|c|}
\hline Patient & $\begin{array}{c}\text { Age } \\
(y)\end{array}$ & $\begin{array}{c}\text { Body } \\
\text { surface } \\
\text { area }\left(m^{2}\right)\end{array}$ & $\begin{array}{c}F E V \\
(I)\end{array}$ & $\begin{array}{l}\frac{F E V_{l}}{F V C} \\
(\%)\end{array}$ & $\begin{array}{l}R V \\
(l)\end{array}$ & $\begin{array}{c}\frac{R V}{T L C} \\
(\%)\end{array}$ & 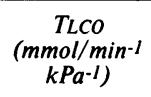 & $\begin{array}{c}\mathrm{PaO}_{2} \\
(\mathrm{~mm} \mathrm{Hg})\end{array}$ & $\begin{array}{c}\mathrm{PaCO}_{2} \\
(\mathrm{~mm} \mathrm{Hg})\end{array}$ \\
\hline 1 & 58 & 1.67 & $\begin{array}{c}0.34 \\
(3.09)\end{array}$ & $\begin{array}{c}20 \\
(70)\end{array}$ & $\begin{array}{c}5.84 \\
(2.33)\end{array}$ & $\begin{array}{c}66 \\
(29)\end{array}$ & $\begin{array}{c}8.0 \\
(9.2)\end{array}$ & 43.3 & 49.3 \\
\hline 2 & 68 & 1.88 & $\begin{array}{c}1.01 \\
(2.78)\end{array}$ & $\begin{array}{c}43 \\
(66)\end{array}$ & $\begin{array}{c}3.85 \\
(2.34)\end{array}$ & $\begin{array}{c}54 \\
(31)\end{array}$ & $\begin{array}{c}8.5 \\
(7.9)\end{array}$ & 57.9 & 42.8 \\
\hline 3 & 66 & 1.98 & $\begin{array}{c}0.61 \\
(2.92)\end{array}$ & $\begin{array}{c}41 \\
(67)\end{array}$ & $\begin{array}{c}3.31 \\
(2.52)\end{array}$ & $\begin{array}{c}56 \\
(30)\end{array}$ & $\begin{array}{c}6.3 \\
(8.9)\end{array}$ & 54.6 & 45.2 \\
\hline 4 & 66 & 1.68 & $\begin{array}{c}0.94 \\
(1.89)\end{array}$ & $\begin{array}{c}42 \\
(75)\end{array}$ & $\begin{array}{c}3.19 \\
(1.75)\end{array}$ & $\begin{array}{c}58 \\
(43)\end{array}$ & $\begin{array}{c}7.3 \\
(6.8)\end{array}$ & 51.1 & 42.3 \\
\hline 5 & 62 & 1.75 & $\begin{array}{c}0.93 \\
(3.18)\end{array}$ & $\begin{array}{c}24 \\
(69)\end{array}$ & $\begin{array}{c}3.49 \\
(2.56)\end{array}$ & $\begin{array}{c}44 \\
(30)\end{array}$ & $\begin{array}{c}5.0 \\
(9.6)\end{array}$ & 77.2 & 33.8 \\
\hline 6 & 61 & 1.69 & $\begin{array}{c}0.54 \\
(2.74)\end{array}$ & $\begin{array}{c}31 \\
(69)\end{array}$ & $\begin{array}{c}3.92 \\
(2.20)\end{array}$ & $\begin{array}{c}61 \\
(29)\end{array}$ & $\begin{array}{c}5.3 \\
(8.2)\end{array}$ & 39.2 & 69.6 \\
\hline 7 & 60 & 1.82 & $\begin{array}{c}0.84 \\
(2.63)\end{array}$ & $\begin{array}{c}37 \\
\text { (69) }\end{array}$ & $\begin{array}{c}4.08 \\
(2.07)\end{array}$ & $\begin{array}{c}57 \\
(29)\end{array}$ & $\begin{array}{c}7.3 \\
(7.8)\end{array}$ & 65.0 & 45.0 \\
\hline 8 & 72 & 1.59 & $\begin{array}{c}0.75 \\
(2.40)\end{array}$ & $\begin{array}{c}36 \\
(65)\end{array}$ & $\begin{array}{c}2.21 \\
(2.38)\end{array}$ & $\begin{array}{c}44 \\
(32)\end{array}$ & $\begin{array}{c}5.5 \\
(7.5)\end{array}$ & 59.1 & 47.4 \\
\hline 9 & 41 & 1.71 & $\begin{array}{c}0.41 \\
(3.55)\end{array}$ & $\begin{array}{c}35 \\
(77)\end{array}$ & $\begin{array}{c}2.82 \\
(1.99)\end{array}$ & $\begin{array}{c}57 \\
(26)\end{array}$ & $\begin{array}{c}6.1 \\
(10.1)\end{array}$ & 62.5 & 42.5 \\
\hline 10 & 68 & 1.44 & $\begin{array}{c}0.63 \\
(2.24)\end{array}$ & $\begin{array}{c}33 \\
(66)\end{array}$ & $\begin{array}{c}3.56 \\
(2.10)\end{array}$ & $\begin{array}{c}60 \\
(31)\end{array}$ & $\begin{array}{c}4.0 \\
(6.9)\end{array}$ & 58.1 & 44.3 \\
\hline $\begin{array}{l}\text { Mean } \\
\pm \text { SEM }\end{array}$ & $\begin{array}{c}62.2 \\
8.6\end{array}$ & $\begin{array}{l}1.72 \\
0.15\end{array}$ & $\begin{array}{l}0.70 \\
0.20\end{array}$ & $\begin{array}{c}34 \\
2.27\end{array}$ & $\begin{array}{l}3.62 \\
0.96\end{array}$ & $\begin{array}{r}55.7 \\
7.0\end{array}$ & $\begin{array}{l}6.3 \\
1.4\end{array}$ & $\begin{array}{l}56.8 \\
3.42\end{array}$ & $\begin{array}{c}46.2 \\
2.9\end{array}$ \\
\hline
\end{tabular}

Conversion: Traditional to SI units - Blood gases: $1 \mathrm{~mm} \mathrm{Hg}=0.133 \mathrm{kPa}$.

$\mathrm{FEV}_{1}=$ forced expiratory volume in one second $\mathrm{FVC}=$ forced vital capacity $; \mathrm{RV}=$ residual volume; $\mathrm{TLC}=$ total lung capacity $\mathrm{TLCO}=\mathrm{transfer}$ factor; $\mathrm{PaO}_{2}=$ arterial oxygen tension; $\mathrm{PaCO}_{2}=$ arterial carbon dioxide tension.

respiratory system. No patient who was asked refused to participate.

Pulmonary function was measured by conventional techniques. ${ }^{19}$ All patients underwent right heart catheterisation and were studied supine and fasting. After 30 minutes' rest arterial gas tensions were measured; expired gases were collected, measured, and analysed for oxygen and carbon dioxide content; and heart rate and intravascular pressures were recorded.

After this, terbutaline $(250 \mu \mathrm{g})$ was injected into the pulmonary artery over 30-45 seconds without the patients' knowledge and ventilatory measurements were repeated after $31 / 2-61 / 2$ minutes, blood samples being taken at 5 minutes. All measurements were repeated 35 minutes after the drug had been given.

Cardiac output, pulmonary vascular resistance, and intravascular pressures were measured and calculated as previously described. ${ }^{19}$ Total systemic vascular resistance was taken as the mean brachial artery pressure divided by the cardiac output. Calculation of tidal volume (VT), respiratory rate, and ventilation was made from the expiratory trace recorded on a Tissot spirometer. Physiological dead space (VD) and the ratio with tidal volume (VD/VT) were calculated from the Bohr equation and the respiratory exchange ratio. Venous admixture (QS/QT) and the alveolar arterial oxygen difference $\left(\mathrm{A}-\mathrm{aDO}_{2}\right)$ were calculated from the shunt equation, the ideal alveolar oxygen tension being obtained from the alveolar gas equation. Alveolar ventilation was calculated as the difference between overall and deadspace ventilation. All measurements have been corrected for body surface area and expressed as the cardiacand

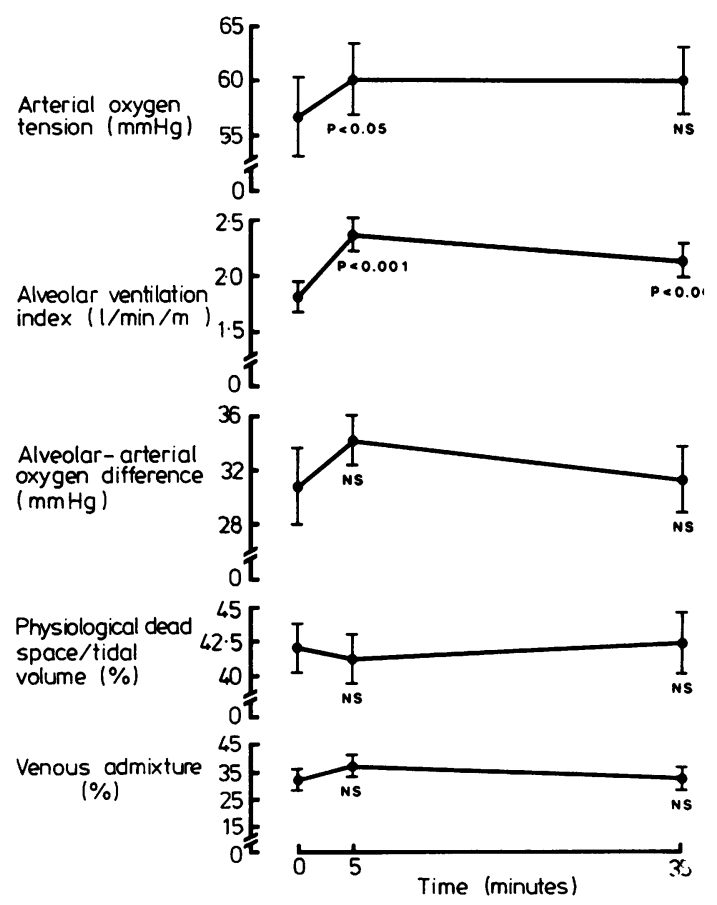

Fig 1 Effects of intravenous terbutaline on arterial oxygen tension, ventilation and ventilation-perfusion relationships in patients with chronic obstructive lung disease and corpulmonale (conversion: traditional to SI units $-1 \mathrm{~mm} \mathrm{Hg}=0.133 \mathrm{kPa}$ ). 
ventilatory index. The significance of any change observed was calculated using a paired Students' $t$ test. Peak expiratory flow rate was recorded at the beginning and the end of each study to confirm that there was no change in airflow obstruction.

\section{Results}

The patients' characteristics and results of lung function testing are shown in the table. The injection of terbutaline caused no noticeable side effects in any of the patients studied.

Effects on arterial gas tensions, ventilation-perfusion relationships, and peak expiratory flow rates

The results are summarised in figure $1 . \mathrm{PaO}_{2}$ rose slightly at 5 minutes from a mean of $56.8(\mathrm{SE} \pm 3.4) \mathrm{mm} \mathrm{Hg}$ to $60.3(\mathrm{SE} \pm 3.2) \mathrm{mm} \mathrm{Hg}(7.6 \pm 0.45$ to $8.0 \pm 0.43 \mathrm{kPa})$, but by 35 minutes the change was nolonger significant. This was accompanied by an increase in the alveolar ventilation index from a mean control level of 1.83 (SE \pm $0 \cdot 14)$ litres $/ \mathrm{min} / \mathrm{m}^{2}$ to $2.37(\mathrm{SE} \pm 0.15) \mathrm{l} / \mathrm{min} / \mathrm{m}^{2}$. This value subsequently fell to $2 \cdot 14(\mathrm{SE} \pm 0 \cdot 16) 1 / \mathrm{min} / \mathrm{m}^{2}$ but was still higher than the control value. There were no changes in venous admixture, $\mathrm{A}-\mathrm{aDo}_{2}$, or $\mathrm{VD} / \mathrm{VT}$ at either 5 or 35 minutes. $\mathrm{PaCO}_{2}$ did not alter from a mean control value of $46.2(\mathrm{SE} \pm 2 \cdot 9) \mathrm{mm} \mathrm{Hg}(6.2 \pm 0.4 \mathrm{kPa})$.

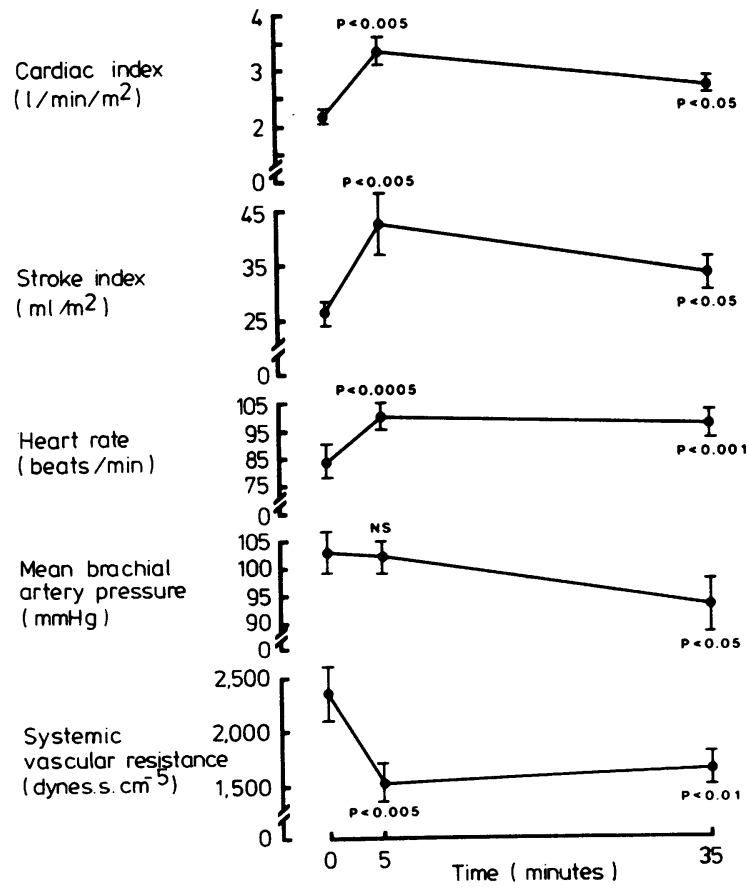

Fig 2 Systemic circulatory effects of intravenous terbutaline in patients with severe chronic obstructive lung disease and corpulmonale (conversion:traditional toSI units $-1 \mathrm{~mm} \mathrm{Hg}=0.133 \mathrm{kPa}$ ).
Effects on systemic circulation

The results are summarised in figure 2. The cardiac index rose from a mean control level of $2 \cdot 17(\mathrm{SE} \pm 0 \cdot 15)$ $1 / \mathrm{min} / \mathrm{m}^{2}$ to $3.36(\mathrm{SE} \pm 0.26) 1 / \mathrm{min} / \mathrm{m}^{2}$ at 5 minutes, falling slightly at 35 minutes to 2.74 (SE \pm 0.16 ) $1 / \mathrm{min} / \mathrm{m}^{2}$, still higher than the control values. This was accompanied by a rise in heart rate at 5 minutes from a $\overrightarrow{0}$ mean control value of $84.4(\mathrm{SE} \pm 5.8)$ to $99.9(\mathrm{SE} \pm 5.2)$ beats/min, falling slightly to $97 \cdot 8(\mathrm{SE} \pm 5 \cdot 3)$ beats/min at $\omega$ 35 minutes. Similarly, the stroke index rose from a mean control level of $26 \cdot 6(\mathrm{SE} \pm 2 \cdot 1)$ to $42 \cdot 5(\mathrm{SE} \pm 5 \cdot 3) \mathrm{ml} / \mathrm{m}^{2}$ at 5 minutes and remained raised at 35 minutes $(33 \cdot 3 \pm 3 \cdot 2 \omega$ $\left.\mathrm{ml} / \mathrm{m}^{2}\right)$. Mean brachial artery pressures, $102 \cdot 6(\mathrm{SE} \pm 3 \cdot 8)$ $\mathrm{mm} \mathrm{Hg}$, did not alter significantly after 5 minutes but had fallen to $93.3(\mathrm{SE} \pm 4.8) \mathrm{mm} \mathrm{Hg}$ at 35 minutes. This $\vec{\circ}$ was accompanied by a widening of the pulse pressure at 5 윽 minutes, which returned to control levels at 35 minutes. -

These changes were reflected in the calculated total $O$ systemic vascular resistance, which fell sharply at $5 \stackrel{\circ}{\circ}$ minutes and rose slightly at 35 minutes, although $\underset{\Phi}{\varnothing}$ remaining below the control values.

Effects on pulmonary circulation, oxygen uptake, and carbon dioxide production

Results are summarised in figure 3 . The increase in car-

Mean pulmonary arterial pressure $(\mathrm{mmHg})$

Pumonary vascular resistance ( dynes. $5 . \mathrm{cm}^{-5}$ )

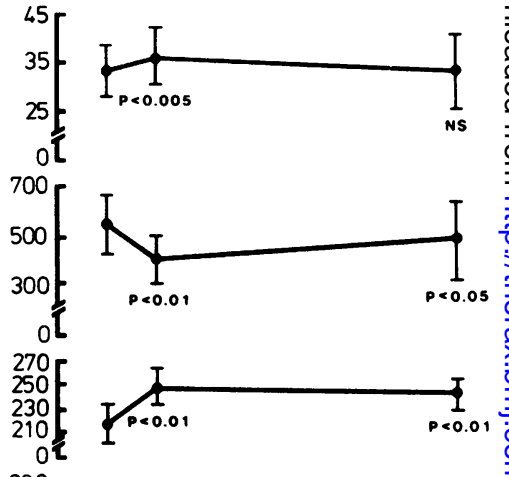

Carbon dioxide production $(\mathrm{ml} / \mathrm{min})$

Oxygen uptake $(\mathrm{ml} / \mathrm{min})$

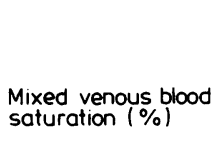

Arterio-venous difference $(\mathrm{ml} \%)$
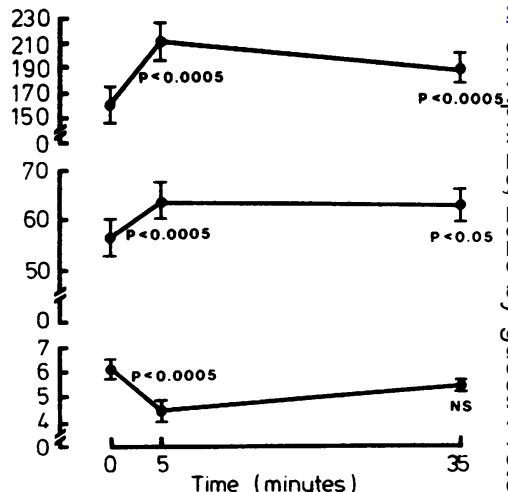

Fig 3 Effects of intravenous terbutaline on the pulmonary circulation of patients with chronic obstructive lung disease and cor pulmonale (conversion: traditional to SI units $-1 \mathrm{~mm} \mathrm{Hg}=0.1330$ $k P a)$. 
diacoutput and hence pulmonary blood flow was accompanied by a small rise in mean pulmonary artery pressure from a control level of $33.0(\mathrm{SE} \pm 5.6) \mathrm{mm} \mathrm{Hg}$ to $36 \cdot 1(\mathrm{SE} \pm 6 \cdot 1) \mathrm{mm} \mathrm{Hg}$ at 5 minutes, with a return to control levels at 35 minutes. There was no change in the mean pulmonary wedge pressure. These changes were reflected in a fall in the calculated pulmonary vascular resistance from a mean control level of $553(\mathrm{SE} \pm 117)$ dynes $\mathrm{s} \mathrm{cm}^{-5}$ to $411(\mathrm{SE} \pm 96)$ dynes $\mathrm{s} \mathrm{cm}^{-5}$ at 5 minutes and $477(\mathrm{SE} \pm 145)$ dynes $\mathrm{s} \mathrm{cm} \mathrm{cm}^{-5}$ at 35 minutes.

Oxygen uptake rose from $218.5(\mathrm{SE} \pm 14.7) \mathrm{ml} / \mathrm{min}$ to $247.6(\mathrm{SE} \pm 15 \cdot 2) \mathrm{ml} / \mathrm{min}$ at 5 minutes and remained raised at $240.9(\mathrm{SE} \pm 11.7) \mathrm{ml} / \mathrm{min}$ at 35 minutes. Similarly, carbon dioxide production increased from a mean control level of 161.9 (SE \pm 11.8$) \mathrm{ml} / \mathrm{min}$ to 210.8 (SE \pm $15 \cdot 7) \mathrm{ml} / \mathrm{min}$ at 5 minutes, also remaining raised ( $186 \cdot 2$ $(\mathrm{SE} \pm 12.4) \mathrm{ml} / \mathrm{min}$ ) at 35 minutes. This was accompanied by a fall in the arteriovenous oxygen difference from $6.0(\mathrm{SE} \pm 0.33) \mathrm{mm} \mathrm{Hg}(0.8 \pm 0.04 \mathrm{kPa})$ to $4.4(\mathrm{SE} \pm 0.43) \mathrm{mm} \mathrm{Hg}(0.6 \pm 0.06 \mathrm{kPa})$ at 5 minutes, with return to control levels at 35 minutes. Mixed venous blood saturation rose from a mean control level of 56.5 $(\mathrm{SE} \pm 3.1) \mathrm{mm} \mathrm{Hg}(7.5 \pm 0.4 \mathrm{kPa})$ to $63.6(\mathrm{SE} \pm 3.7) \mathrm{mm}$ $\mathrm{Hg}(8.5 \pm 0.5 \mathrm{kPa})$ at 5 minutes and remained raised at $62 \cdot 3(\mathrm{SE} \pm 2 \cdot 77) \mathrm{mm} \mathrm{Hg}(8 \cdot 3 \pm 0.37 \mathrm{kPa})$ at 35 minutes.

\section{Discussion}

Halmagyi and Cotes ${ }^{4}$ suggested that agents affecting cardiac output and pulmonary vascular resistance may give rise to increased venous admixture, thereby reducing arterial oxygen tension in patients with chronic airflow obstruction, particularly if pulmonary hypertension is present. Terbutaline is one such agent but as its action is largely selective and directed to $\beta_{2}$ receptors with a much less pronounced action on the heart ${ }^{10-16}$ it would be expected to have fewer adverse effects on ventilation-perfusion relationships. This assumption has been confirmed in both reversible ${ }^{9}{ }^{16}$ and irreversible airflow obstruction, with ${ }^{19}$ and without cor pulmonale. ${ }^{17}$ Nevertheless, in several studies a small and unpredictable fall in $\mathrm{PaO}_{2}$ has been noted in some of the patients studied, 91718 although there are no studies relating to early cardiopulmonary changes when drug concentrations are at their highest.

In the present study nosignificant changes were noted in any of the indices of ventilation-perfusion inequality at either 5 minutes or 35 minutes after the drug was given, although the $\mathrm{PaO}_{2}$ rose initially in all but one patient. The maximum rise observed was in patient 2 , from $57.9 \mathrm{~mm} \mathrm{Hg}(7.7 \mathrm{kPa})$ to $72.5 \mathrm{~mm} \mathrm{Hg}(9.64 \mathrm{kPa})$. The only patient (No 5) in whom the $\mathrm{PaO}_{2}$ fell had the highest resting $\mathrm{PaO}_{2}-77.0 \mathrm{~mm} \mathrm{Hg}(10.24 \mathrm{kPa})$-and least physiological impairment of lung function as well as the lowest resting venous admixture (12\%) and mean pulmonary artery pressure $(18 \mathrm{~mm} \mathrm{Hg})$. Although the changes in $\mathrm{PaO}_{2}$ after bronchodilator drugs may be unpredictable, ${ }^{21}$ in the present study the patients with the lowest resting $\mathrm{PaO}_{2}$ and highest pulmonary vascular resistance all experienced a transient rise in $\mathrm{PaO}_{2}$. This suggests that there is only a small risk of a dangerous fall in $\mathrm{PaO}_{2}$ even in the most severely affected patients.

The rise in $\mathrm{PaO}_{2}$ was unexpected but accompanied by an increase in alveolarventilation. Possibly this reflects a direct action of terbutaline on chemoreceptors increasing ventilatory drive, as similar changes have been noted for salbutamol, ${ }^{25}$ but further studies will be necessary to clarify this point. No changes were observed in $\mathrm{PCO}_{2}$ despite the increase in alveolar ventilation. This may be explained by a rise in oxygen uptake and carbon dioxide production as a result of the increased ventilatory work, which may have partly offset the effect of increased ventilation on $\mathrm{PaCO}_{2}$.

The increase in cardiac output, stroke volume, and heart rate at 5 minutes were expected and were associated with an appreciable fall in total systemic vascular resistance but no early change in mean brachial artery pressure. Later, at 35 minutes, the brachial artery pressure had fallen significantly and was accompanied by small reductions in both stroke index and cardiac index compared with the 5-minute value. The heart rate did not change from the 5-minute value but remained significantly raised. These early changes cannot be explained solely by a reflex response to systemic vasodilatation and hypotension, as has been suggested, ${ }^{19} 22$ for two reasons. Firstly, no early fall in blood pressure was recorded and, secondly, all measurements were made in the supine position, where postural effects would be minimal. ${ }^{17}$ Nevertheless, the blood pressure did fall at 35 minutes in the presence of a lower cardiac output but a sustained increase in heart rate, which is more typical of a predominant $\beta_{2}$ effect. The $\beta_{1}$ effects of terbutaline are dose related however, and thus the early changes, when drug concentrations are highest, are probably due to a combination of the $\beta_{1}$ effect on the heart and $\beta_{2}$ peripheral vasodilation. Later, as serum concentrations decline, the $\beta_{1}$ effect is less prominent than the sustained $\beta_{2}$ action. This would explain the sustained tachycardia at 35 minutes, which is probably due largely to a reflex response to systemic hypotension and systemic vasodilatation ( $\beta_{2}$ effects). ${ }^{13.14}$

The mean pulmonary artery pressure rose transiently with cardiac output and pulmonary vascular resistance fell. By 35 minutes the pulmonary artery pressure had returned to resting levels, although the cardiac output remained raised and pulmonary vascular resistance reduced. This may reflect changes in pulmonary vascular capacitance in response to the increased cardiac output rather than a direct $\beta_{2}$ vasodilating effect of terbutaline on pulmonary resistance vessels ${ }^{23}$ although either or both mechanisms may be operating.

In summary, terbutaline sulphate in the dose used 
had no major detrimental effects on gas exchange in the patients studied. The effects on the cardiovascular system were more noticeable at 5 minutes, when drug concentrations are likely to be at their highest, and suggest a combined $\beta_{1}$ and $\beta_{2}$ response. It is concluded that terbutaline in this dose can be given to such patients without worsening their gas exchange and that it may even produce a temporary improvement.

We would like to thank Miss J Downs for her typing and $\mathrm{Mr} \mathrm{BJ}$ Milton for technical assistance.

\section{References}

' Knudson RJ, Constantine HP. An effect of isoproterenol on ventilation-perfusion in asthmatic versus normal subjects. J Appl Physiol 1967;22:402-6.

2 Palmer KNV, Diament ML. Spirometry and blood gas tensions in bronchial asthma and chronic bronchitis. Lancet 1967;ii:383-4.

${ }^{3}$ Palmer KNV, Legge JS, Hamilton WFD, et al. Comparison of effect of salbutamol and isoprenaline on spirometry and blood gastensions in bronchial asthma. BrMedJ1970;ii:234.

${ }^{4} \mathrm{Halmagyi}$ DF, Cotes JE. Reduction in systemic blood oxygen as a result of procedures affecting the pulmonary circulation in patients with chronic pulmonary disease. Clin Sci 1959;18:475-84.

${ }^{5}$ Daly JJ, Howard P. Effect of intravenous aminophylline on arterial oxygen in chronic bronchitis. Thorax 1965;20:3246.

${ }^{6}$ Streeton JA, Morgan EB. Salbutamol in status asthmaticus and severe chronic obstructive bronchitis. Postgrad Med J 1971;47, suppl:125-8.

${ }^{7}$ Harris LH. Effects of isoprenaline plus phenylephrine by pressurised aerosol on blood gas ventilation and perfusion in chronic obstructive lung disease. $\mathrm{Br}$ Med J 1970; iv:57982.

${ }^{8}$ Harris LH. Comparison of the effect on blood gases, ventilation and perfusion of isoproterenol-phenylephrine and salbutamol aerosols in chronic bronchitis with asthma. $J$ Allergy Clin Immunol 1972;49:63.

${ }^{9}$ Harris LH. Comparison of cardiorespiratory effects of terbutaline and salbutamol aerosols in patients with reversible airways obstruction. Thorax 1973;28:592-5.

${ }^{10}$ Carlström S. Introductory remarks [to studies on terbutaline]. Acta Med Scand 1970; suppl 512:7-9.

"Persson H, Olsson T. Some pharmacological properties of terbutaline (INN), 1-3.5-dihydroxyphenyl)-2-( $t$-butylamino)-ethanol. A new sympathomimetic, $\beta$-receptor stimulating agent. Acta Med Scand 1970; suppl 512:11-9.
${ }_{12}$ Persson H, Johnson B. A dual preparation technique for studying the differentiation of the effect of sympathomimetic agents on heart and tracheal muscle. Acta Med Scand 1970; suppl 512:21-4.

${ }^{13}$ Carlström S, Westling H. Metabolic circulatory and respiratory effects of a new sympathomimetic $\beta$-receptor stimulating agent terbutaline compared with those of orciprenaline. Acta Med Scand 1970; suppl 512:33-4.

${ }^{14}$ Arner B, Bertler A, Karlefers T, Westling H. Circulatory effects of orciprenaline, adrenaline and a new sympathomimetic $\boldsymbol{\beta}$-receptor stimulating agent, terbutaline, in normal human subjects. Acta Med Scand 1970; suppl 512:25-32.

${ }^{15}$ Arner B. A comparative trial of different subcutaneous doses of terbutaline and orciprenaline in bronchial asthma. Acta Med Scand 1970; suppl 512:45-8.

${ }^{16}$ Amory DW, Burnham SC, Cheney FWJ. Comparison of the cardiopulmonary effects of subcutaneously administered epinephrine and terbutaline in patients with reversible airway obstruction. Chest 1974;67:279.

${ }^{17}$ Teule GJJ, Majid PA. Haemodynamic effects of terbutaline in chronic obstructive airways disease. Thorax 1980;35:536-42.

${ }^{18} \mathrm{Da}$ Costa J, Helstrand U. The effect of a new sympathomimetic beta-receptor stimulating drug (terbutaline) on arterial blood gases in bronchial asthma. Scand J Respir Dis 1970;51:212-7.

${ }^{19}$ Stockley RA, Finnegan P, Bishop JM. Effect of intravenous terbutaline on arterial blood gas tensions ventilation and pulmonary circulation in patients with chronic bronchitis and cor pulmonale. Thorax 1977;32:601-5.

${ }^{20}$ Davies DS. Metabolism of adrenaline-like bronchodilator drugs. Proceedings of United Kingdom-Scandinavian Conference on bronchodilatation. Watford: Astra Chemicals Ltd, 1972:87-99.

${ }^{21}$ Holten K. Bronchodilator effects and effects on blood gases after subcutaneous injection and inhalation of terbutaline. BrJ Dis Chest 1974;68:111-20.

${ }^{22}$ Gibson, DG, Coltart DJ. Haemodynamic effects of intravenous salbutamol in patients with mitral valve disease: comparison with isoprenaline and atropine. Postgrad Med J 1971;47, suppl:40-4.

${ }^{23}$ Harris P, Segel N, Bishop JM. The relation between pressure and flow in the pulmonary circulation in normal subjects and in patients with chronic bronchitis and mitral stenosis. Cardiovasc Res 1968;2:73-83.

${ }^{24}$ Cotes JE. Lung function. 4th ed. Oxford: Blackwell Scientific No Publications, 1979.

${ }^{25}$ Leitch AG, Clancy LJ, Costello JF, Flenley DC. Effect of intravenous salbutamol on ventilatory response to carbon dioxide and hypoxia and on heart rate and plasma potassium in normal subjects. Br Med J 1976; ;:365-7. 